\title{
Smudge Cells to Leukocytes Ratio Measurement
}

National Cancer Institute

\section{Source}

National Cancer Institute. Smudge Cells to Leukocytes Ratio Measurement. NCI

Thesaurus. Code C119294.

The determination of the ratio of smudge cells to leukocytes in a biological specimen. 